\title{
Adipose-derived Stem Cells Promote Skin Homeostasis and Prevent its Senescence in an In vitro Skin Model
}

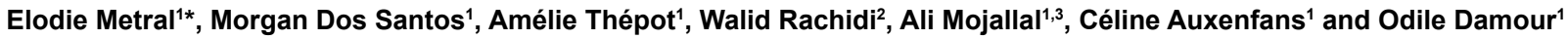

${ }^{1}$ Banque de tissus et cellules, Laboratoire des substituts cutanés, Hôpital Edouard Herriot, 5, place d'Arsonval, Pavillon i, 69437, Lyon, France. Hospices Civils de Lyon and LBTI, UMR 5305, France

2INAC/SCIB/LAN, CEA de Grenoble, 17 Rue des Martyrs, 38054, Grenoble, France

${ }^{3}$ Department of Plastic surgery, Hospices Civils de Lyon, University of Lyon, France

\begin{abstract}
Objectives: Skin aging is subject of many studies in esthetic surgery including several morphological changes like decrease of epidermis thickness and of cell proliferative potential. ASC, mesenchymal stem cells derived from adipose tissue, have been used in regenerative and reparative surgery as well as anti-aging solution. The aim of this study was to highlight the influence of ASCs on skin aging and healing in an in vitro skin model.

Methods: Using an skin equivalent (SE) model prepared without or with ASCs in different proportion (25\% or $50 \%$ of ASCs), beneficial influence of ASCs on epidermal regeneration via markers of proliferative and differentiative potential and on quality of the dermis via markers of dermal protein synthesis was analyzed. In addition, an extendedtime cultured model mimicking skin ageing was used to demonstrate ASCs influence on skin aging via markers of the quality of the epidermis and dermis as well as via a marker of senescence.

Results: After 42 days of culture, SEs prepared with $25 \%$ of ASCs were thicker, presented a better proliferative potential showed by a higher number of Ki67 positive cells, and a better differentiation in epidermis. A better fibroblast synthesis in dermis was also showed. Skin ageing was studied by prolonging culture time : SEs prepared with $25 \%$ of ASCs showed remained Ki67 positive cells and a low level of senescent marker, p16, labeling, whereas SEs with fibroblasts alone were very thin, free of proliferative cells and with a high p16 expression.

Conclusions: To conclude, adding ASCs in low proportion (25\%) improved quality of the epidermis and dermis preventing senescence of the SE model. This confirms clinical results and supports their anti-aging effect and their potential in wound healing. In addition, this model provides a tool to elucidate the mode of action of ASCs on healing and skin aging.
\end{abstract}

Keywords: Skin aging; Senescence; Wound healing; Skin equivalent model; Cell therapy; Adipose derived stem cell; Keratinocytes

\section{Introduction}

As one of the most visible signs of aging in a human being, aging of the skin is the subject of many studies in aesthetic and cosmetic surgery. The effects of aging are felt at the skin level in various forms, including genetic, biochemical and morphological. The thinning of the epidermis is one of the morphological signs of skin aging, due to a slowdown in keratinocyte proliferation and loss of differentiation into corneocytes [1-3]. Moreover, the dermal-epidermal junction flattens and becomes linear with the loss of dermal papillae [4]. The dermis becomes thinner, with modifications in its collagen and elastin fiber composition and in its architecture, altering its mechanical properties [5-7]. Clinical changes are thus observed in the elderly: beside the thickness, the skin becomes, drier and less toned, resulting in the formation of wrinkles and a greater visibility of the underlying vascular network, which becomes more fragile.

Several methods have been used in cosmetic surgery to compensate for the aging process and its effects. Injecting wrinkles with filler is a less invasive technique than a facelift to reduce or eradicate them. Dermal fillers can be biodegradable or not and are available in various chemical or biochemical forms [8]. Compared to absorbable products of short duration, such as collagen and hyaluronic acid [8], adipose tissue injections provide several advantages: they are autologous, biocompatible and long-lasting $[9,10]$.

The first adipose tissue transplant was performed to fill in a facial scar [11]. It has been used since to increase the volume of several areas of the face and to fill in wrinkles [12], as well as on other areas of the body such as the back of the hand [13] and the chest $[14,15]$. In addition to the filling effect of adipose tissue, clinical improvement to skin quality has also been observed: scars become almost invisible and the skin becomes thicker [10]. This effect was quickly attributed to Adipose Stem Cells (ASCs) contained in the stromal vascular fraction (SVF) from which they are derived. ASCs are mesenchymal stem cells (MSC), which share the same markers than other MSC like those isolated from bone marrow or umbilical cord [16,17]. As other adult mesenchymal stem cell, they possess the ability to adhere to plastic, to self-renew and to differentiate into various cell types like adipocytes, osteoblatses, chondroblasts and myoblasts $[18,19]$.

ASC enrichment techniques have led to improved clinical outcomes [20-25]. However, the SVF of adipose tissue, a cell suspension, contains a small and variable amount of stem cells (between 2 and 10\%) [2629], which might explain the individual variations observed in

*Corresponding author: Metral E, Cell and Tissue Bank, Cutaneous Substitute Laboratory, Hôpital Edouard Herriot, 5, place d'Arsonval, Pavillon i, 69437, Lyon, France, Tel: +33 47206 27; Fax: +33 47296 49; E-mail: metral.elodie@gmail.com

Received March 17, 2014; Accepted April 10, 2014; Published April 12, 2014

Citation: Metral E, Santos MD, ThépotA, Rachidi W, Mojallal A, etal. (2014) Adiposederived Stem Cells Promote Skin Homeostasis and Prevent its Senescence in an In vitro Skin Model. J Stem Cell Res Ther 4: 194. doi:10.4172/2157-7633.1000194

Copyright: ( 2014 Metral E, et al. This is an open-access article distributed under the terms of the Creative Commons Attribution License, which permits unrestricted use, distribution, and reproduction in any medium, provided the original author and source are credited. 
clinical outcomes, such as for facial fillers [30]. More recently, it was proposed that the culture of ASCs would give pure pre-determined ASC cell suspensions that could provide valuable solutions for volume restoration and skin rejuvenation [31].

This regenerative potential of adipose tissue (AT) and cultured ASCs was quickly tested on the healing of chronic wounds. When injected around the wound they accelerated complete wound closure [32-35]. Furthermore, it was shown that ASCs cultured in a monolayer secrete growth factors that have an effect on fibroblast and keratinocyte proliferation [36-44] and an immunomodulatory effect on the inflammatory response (reviewed by $[45,46]$ ). Finally, these multipotent cells could also act by differentiating into different skin cell lines [35,47-50]. Furthermore, our preclinical trials on ASCs implanted in mouse and pig hypodermis have shown a significant increase in dermal thickness [51,52].

The objective of this in-vitro study was to highlight the influence of ASCs on skin quality using an evolving skin equivalent (SE) model that allowed cell-cell or cell-matrix interactions to be studied. In order to do this, we compared SE prepared with and without ASCs and showed its beneficial influence on epidermal regeneration through markers of proliferative and differentiative potential and on quality of the dermis via markers of dermal protein synthesis. Finally we demonstrated their influence on skin aging via markers of the quality of the epidermis and dermis as well as via a marker of senescence, in an extended-time cultured model mimicking skin aging.

\section{Methodology Applied}

\section{Tissues harvest}

Normal human skin and lipoaspirate samples were obtained from anonymous healthy donors. Surgical residue was harvested according to French regulation and declared to research ministry $\left(\mathrm{DC} \mathrm{n}^{\circ} 2008162\right)$ and written informed consent was obtained from the patient.

\section{Keratinocytes and fibroblasts isolation and characterisation}

For cells isolation, the dermal and epidermal compartments were separated by enzymatic treatment using thermolysine (Sigma, St Quentin Fallavier, France) overnight at $4^{\circ} \mathrm{C}$. Epidermal cells were then isolated using a trypsin treatment (Invitrogen, Carlsbad, USA) whereas collagenase $(0.120 \mathrm{U} / \mathrm{ml})$ (Roche, Indianapolis, USA) was used for dermal digestion. Cell suspensions were then centrifuged (300 gmin $^{-1}$ for $5 \mathrm{~min}, 20^{\circ} \mathrm{C}$ ) and cells were counted using trypan blue $0,04 \%$ (hospital pharmaceutical preparation) and selected by adhesion on plastic culture dish.

Cell numeration and viability using trypan blue staining was always performed after each tryspsinization before seeding a controlled density both for cell amplification and SE preparation. Microscopic observations including fusiform mesenchymal aspect of fibroblasts and cobblestone aspect of keratinocytes were used to characterize them routinely as well as colony forming efficiency for their potency.

\section{ASC isolation and characterization}

Human stromal vascular fraction (SVF) was isolated from lipoaspiration undergoing optimized liposuction using a $3 \mathrm{~mm}$ canulae according to Björntorp [53,54]. Briefly, adipose tissue was digested with collagenase at $37^{\circ} \mathrm{C}$ for $30 \mathrm{~min}$ and under constant shaking. Digestion was stopped by adding Dulbecco's Modified Eagle's Medium (DMEM with glutamax, Gibco (Invitrogen, Carlsbad, USA) containing
$10 \%$ foetal calf serum (FCS, HyClone, Logan, USA). Floating adipocytes were discarded and cells from the SVF were pelleted, rinsed with media, centrifuged $\left(300 \mathrm{~g} . \mathrm{min}^{-1}\right.$ for $5 \mathrm{~min}, 20^{\circ} \mathrm{C}$ ) and incubated in an erythrocyte lysis buffer $(\mathrm{NH} 4 \mathrm{Cl})$ for $10 \mathrm{~min}$ at $37^{\circ} \mathrm{C}$. This cell suspension was centrifuged $\left(300 \mathrm{gmin}^{-1}\right.$ for $5 \mathrm{~min}, 20^{\circ} \mathrm{C}$ ) and cells were counted using trypan blue and selected by adhesion on plastic culture dish.

Cell numeration and viability using trypan blue staining was always performed after each tryspsinization before seeding a controlled density both for cell amplification and SE preparation. ASC were characterised by expression of CD 105, 90, 73, 14 and 45 by flow cytometry with a specification of $>95 \%$ for CD 105, 90, 73 and $<2 \%$ for CD 14 and 45. Moreover cloning forming efficiency was also performed with specification of $>3 \%$. Finally, their multipotency was confirmed by their capacity to differentiate into adipocytes [55], endothelial cells [56] and osteoblasts.

\section{Monolayer cell culture}

Fibroblasts were grown in Dulbecco's modified Eagle's medium supplemented with $10 \%$ foetal calf serum (FCS), $20 \mathrm{mg} / \mathrm{mL}$ gentamicin (Panpharma, Fougères, France), $100 \mathrm{IU} / \mathrm{mL}$ penicillin (Panpharma, Fougères, France), and $1 \mathrm{mg} / \mathrm{mL}$ amphotericin B (Panpharma, Fougères, France).

Keratinocytes were grown on a feeder layer of irradiated human fibroblasts as described by Rheinwald and Green [57] in a 3:1 mixture of DMEM and Ham's F12 (Invitrogen, Carlsbad, USA), respectively, supplemented with $10 \% \mathrm{FCS}, 10 \mathrm{ng} / \mathrm{mL}$ epidermal growth factor (EGF) (Austral Biologic, San Ramon, California), $0.12 \mathrm{IU} / \mathrm{mL}$ insulin (Lilly, Saint-Cloud, France), $0.4 \mathrm{mg} / \mathrm{mL}$ hydrocortisone (UpJohn, St Quentin en Yvelines, France), $5 \mathrm{mg} / \mathrm{mL}$ triiodo-L-thyronine (Sigma, St Quentin Fallavier, France), $24.3 \mathrm{mg} / \mathrm{mL}$ adenine (Sigma, St Quentin Fallavier, France), isoproterenol (isuprel, Hospira France, Meudon, France) and antibiotics.

Adipose derived stem cells (ASC) were grown in a 1:1 mixture of DMEM and Ham's F12, respectively, supplemented with $10 \%$ FCS, $10 \mathrm{ng} / \mathrm{mL}$ basic fibroblast growth factor (bFGF or FGF2) (Sigma, St Quentin Fallavier, France), and antibiotics.

For each cell type, medium was changed every three days until confluence was reached. At confluency, cells were resuspended with trypsin-EDTA 0, 01\% (Invitrogen, Carlsbad, USA) and used for in vitro 3D model.

\section{In vitro $3 \mathrm{D}$ human skin equivalent $(\mathrm{SE})$ culture}

For the preparation of dermal equivalent (DE), three independent suspensions were prepared: fibroblasts alone, fibroblasts and ASC in $1: 1$ or $1: 3$ proportions. Each final cell suspension were seeded at a final density of $250000 \mathrm{cells} / \mathrm{cm}^{2}$ (fibroblasts + ASCs) onto a dermal substrate made of chitosan-cross-linked collagen-glycosaminoglycans matrix prepared as previously described [58]. This DE was grown in fibroblast medium supplemented with $50 \mathrm{mg} / \mathrm{mL} \mathrm{L}$-ascorbic acid (Aguettant, Lyon, France) at $37^{\circ} \mathrm{C}$ in a $5 \% \mathrm{CO}_{2}$ atmosphere and changed every day for 14 days.

For the preparation of SE, keratinocytes from young donor were seeded onto the DE on day 21 [59]. These submerged cultures were cultured 7 days in keratinocyte medium supplemented with $50 \mathrm{mg} /$ $\mathrm{mL} \mathrm{L-ascorbic} \mathrm{acid} \mathrm{at} 37^{\circ} \mathrm{C}$ in a $5 \% \mathrm{CO}_{2}$ atmosphere and changed every three days. Then, SEs were raised at the air-liquid interface 
and cultured in a simplified keratinocyte medium containing DMEM supplemented with $10 \%$ FCS, $10 \mathrm{ng} / \mathrm{mL}$ EGF, $0.12 \mathrm{IU} / \mathrm{mL}$ insulin, 0.4 $\mathrm{mg} / \mathrm{mL}$ hydrocortisone, and antibiotics, for 14 days, 32 days or 72 days.

SEs of each condition (DE prepared with fibroblasts alone $(=\mathrm{DE}$. Fibroblasts), DE prepared with fibroblasts and ASC in 1:1 proportion (=DE. Fibroblasts + ASC 50\%) and DE prepared with fibroblasts and ASC in 1:3 proportion (=DE. Fibroblasts + ASC 25\%) were harvested at day 42 (D42), 60 (D60) and 100 days (D100) of total culture. SEs were immediately fixed in neutral buffered formalin $4 \%$ (Diapath, Martinengo, Italy) for $24 \mathrm{~h}$ and embedded in paraffin, or in OCT compound (euromedex, Strasbourg, France) and frozen at $-20^{\circ} \mathrm{C}$. All SEs were produced in triplicate.

\section{Histology and immunohistological (IH) analysis}

Paraffin-embedded formalin-fixed samples were then cut into $5 \mu \mathrm{m}$ sections. After dewaxing and rehydration, sections were stained with haematoxylin - phloxin - saffron (HPS staining). For immunohistochemistry, after enzyme-mediated antigen retrieval treatment (hyaluronidase (Sigma, St Quentin Fallavier, France) $45 \mathrm{~min}$ at $37^{\circ} \mathrm{C}$ ) for decorin and heat-mediated antigen retrieval treatment for p16, tissue sections were incubated in $5 \% \mathrm{H}_{2} \mathrm{O}_{2} / 3 \%$ normal goat serum (NGS; Jackson Immunoresearch, Suffolk, UK) to inactivate endogenous peroxydases. Non-specific binding was blocked in PBS containing 5\% of NGS. Sections were then incubated with the following primary antibodies diluted in PBS / NGS 5\% overnight at $4^{\circ} \mathrm{C}$ : anti-decorin 1/1000 (abcam, Paris, France), anti-p16 1/250 (abcam, Paris, France). After incubation for 1 hour with the peroxydase-conjugated secondary antibody (EnVision, Dakocytomation, Glostrup, Denmark), the antigen was detected with 3,3-diaminobenzidine tetrahydrochloride (EnVision, Dakocytomation, Glostrup, Denmark) as the substrate. Tissue sections were subsequently counterstained using Harris hematoxylin (25\%, Sigma, St Quentin Fallavier, France).

For immunofluorescence, labelling was performed on air-dried 5 $\mu \mathrm{m}$ cryosections for fibrillin and on paraffin-embedded $5 \mu \mathrm{m}$ sections for Ki67, K15 and fillagrin. Paraffin-embedded sections were dewaxed and rehydrated before heat-mediated antigen retrieval treatment. Then, air-dried cryosections and paraffin-embedded sections were incubated with monoclonal-mouse primary antibodies to fillagrin 1/25 (clone 15C10, Vector Labs, CA US), Ki67 1/50 (clone MIB1, EnVision, Dakocytomation, Glostrup, Denmark), K15 1/20 (Clone LKH15, Thermo Fisher Scientific, Massachusetts, USA) and fibrillin 1/100 (clone 11C1.3, Neo-markers, Fremont, USA) over-night at $4^{\circ} \mathrm{C}$. Secondary Alexa-488-conjugated anti-mouse antibody (Molecular Probes, Invitrogen, Carlsbad, USA) was incubated 1 hour at room temperature. Nuclear counterstaining using Hoescht was carried out routinely.

As a negative control, primary antibody was replaced by the $\operatorname{IgG}$ class corresponding.

\section{$\beta$-Galactosidase assay}

$\beta$-Galactosidase assay was performed on air-dried $5 \mu \mathrm{m}$ cryosections. Sections were fixed with formalin 1\% (Merck, Darmstadt, Germany) during $1 \mathrm{~min}$ at room temperature. Then, they were incubated for 16 hours at $37^{\circ} \mathrm{C}$ in a solution composed of $1 \mathrm{mg} / \mathrm{mL}$ of X-Gal (Applichem lifescience, Darmstadt, Germany), $40 \mathrm{mM}$ citric acid/ sodium phosphate ( $\mathrm{pH}$ 6,0) (Merck, Darmstadt, Germany), 5 $\mathrm{mM}$ of $\mathrm{K}_{4}\left(\mathrm{Fe}\left(\mathrm{CN}_{6}\right)\right) 3 \mathrm{H}_{2} 0$ (Merck, Darmstadt, Germany), $5 \mathrm{mM}$ of $\mathrm{K}_{3}\left(\mathrm{Fe}\left(\mathrm{CN}_{6}\right)\right.$ ) (Merk, Darmstadt, Germany) $150 \mathrm{mM}$ of NaCl (Merck,
Darmstadt, Germany) and $2 \mathrm{mM}$ of $\mathrm{MgCl}_{2}$ (Merck, Darmstadt, Germany) and finally rinsed with PBS.

\section{Image analysis and processing}

Image acquisition was performed using an Axioskop 2 Plus optical microscope (Carl Zeiss, Le Pecq, France) with a Ds-Ril CCD camera (Nikon, Champigny sur Marne, France) for light microscopy. Fluorescence was visualized using a LSM700 laser scanning confocal microscope (Carl Zeiss).

Image processing and analysis were performed using the software MBF_ImageJ for microscopy (Research Service Branch, US National Institute of Health, United States).

Epidermal thickness was obtained by measuring the distance between the basal lamina and the top of the epidermis excluding the stratum corneum. Conversion from numbers of pixels and $\mu \mathrm{m}$ was made related to a scale included in the software. Nine different fields per experimental condition were quantified. Data are expressed in $\mu \mathrm{m}$.

For proliferative capacity, number of Ki67 positive-cells was counted in 3 fields of 3 samples for each condition by 3 different persons.

Percentage of labelled area was obtained by measuring the number of pixels stained, which was determined by a labelling superior to an intensity threshold precisely defined and identic for each condition, related to the total area. The threshold was defined from the condition in which the labelling was the less intense. The total area was defined as the epidermis (excepted stratum corneum) + the dermis or only the dermis and selected in the same way for each condition. Nine different fields per experimental condition were quantified. Data are expressed in percentage of labelled area.

In figures, each presented mean value was calculated for 3 fields in 3 samples for each condition.

\section{Statistical analysis}

For all data, the statistical significance was assessed running MannWhitney test by using the software SPSS, and statistically significant differences are indicated by asterisks as follows: ${ }^{*} \mathrm{P} \leq 0.05$.

\section{Results}

ASCs increase epidermis thickness after 42 days of culture, corresponding to 14 days of air-liquid interface culture

Histological analysis showed that the addition of adipose stem cells (ASCs) to fibroblasts during seeding of the dermal substrate permitted skin reconstruction with significantly increased epidermal thickness (Figure 1A), regardless of their proportion (25\% ( $\mathrm{p}=0.05)$ or $50 \%$ $(\mathrm{p}=0.05)$ of the seeded cells in the dermis equivalent (DE). However, when DEs were seeded with cell suspension comprised 25\% ASCs and $75 \%$ fibroblasts, the epidermal thickness was 3.2 times higher (with a value of $93.9 \mu \mathrm{m}$ ) than SEs prepared with $100 \%$ fibroblasts (with a value of $29.1 \mu \mathrm{m}$ ), whereas it was only 2.5 times higher with a DE prepared with $50 \%$ fibroblasts and $50 \%$ ASCs (with a value of $72.9 \mu \mathrm{m}$ ) (Figure $1 \mathrm{C})$.

\section{ASCs activate proliferation and accelerate epidermal differentiation}

The results of the immunohistological (IH) analysis on the influence of ASCs on the proliferation and differentiation of epidermal 
keratinocytes are shown in Figure 1A. The following were used: Ki67 as proliferation marker, $\mathrm{K} 15$ as stem cell marker, and filaggrin as terminal differentiation marker.

After 42 days of culture, IH analysis showed that the number of Ki67-positive cells, a proliferation marker, had significantly increased ( $\mathrm{p}=0.05)$ when fibroblasts and ASCs were seeded at a $75 \% / 25 \%$ density with a mean value of $18 \mathrm{Ki} 67$ positive-cells per field for this condition compared to a mean value of $6 \mathrm{Ki} 67$ positive-cells per filed for fibroblast alone, whereas with a $50 \% / 50 \%$ density of ASCs and fibroblasts alone, there was only a trend to increase at this culture time (Figure 1B).

The results were identical with K15 (Figure 1A): this is rarely expressed when the skin is reconstructed using fibroblasts alone, weakly with $50 \% / 50 \%$ density and strongly with a density of $75 \%$ fibroblasts and 25\% ASCs. Regarding epidermal differentiation, on day 42, filaggrin, a terminal differentiation marker of the granular layer, was highly expressed when $25 \%$ ASCs were added to the fibroblasts during skin reconstruction and weakly expressed when $50 \%$ were added (Figure 1A). On the other hand, in control epidermis with $100 \%$ fibroblasts (i.e. $0 \%$ ASCs), its expression was only just weakly detectable.

After 60 days of culture corresponding to 32 days of air-liquid interface culture, the epidermal thickness of the SE and the number of proliferating cells, labelled with Ki67 appeared similar (not statistically different) in SE with 25\%,50\% and without ASCs (Figure 2B and 2C). Similarly, K15 was expressed by virtually all basal layer cells regardless of the conditions (Figure 2A). Filaggrin was also strongly expressed in epidermis with $50 \%$ ASCs and in control epidermis (Figure 2A). These results suggest that differentiation appears at an earlier stage when ASCs are incorporated at a $25 \%$ density. Note that the SE models did not flake and the stratum corneum accumulated and autofluoresced, especially with skin composed of $25 \%$ ASCs.

On day 100, the thickness of the epidermis and the number of Ki67positive cells had significantly increased compared to other conditions in the SE prepared with 25\% ASCs (Figure 2B and 2C). Indeed, SEs prepared with fibroblasts alone had a mean thickness of $10,9 \mu \mathrm{m}$ whereas those prepared with $75 \%$ of fibroblasts and $25 \%$ of ASCs had a mean thickness of $22,6 \mu \mathrm{m}(\mathrm{p}=0.05)$. For proliferative potential, when fibroblasts alone were used for DEs, the numbers of Ki67 positive-cells was 0.1 per field whereas when a suspension of $75 \%$ of fibroblasts and $25 \%$ of ASCs was used, this number is 4,3 ( $\mathrm{p}=0.046$ ).

Thus, kinetics showed that keratinocyte proliferation accelerated when ASCs were added to fibroblasts, notably in $25 \% / 75 \%$ proportions, respectively. This proliferating phase reached a maximum level, inducing a maximal epidermal thickness more rapidly under these conditions. In addition, ASCs not only gave a thick and differentiated epithelium faster but also delayed its senescence, thus increasing its lifespan.

Histological and immunohistological results showed that greater epidermal thickness was the result of increased keratinocyte proliferation in conjunction with complete terminal differentiation. Hence, epidermal homeostasis was maintained. The ASCs thus had a beneficial effect on the epidermis, the best result occurring with $75 \%$ fibroblasts and 25\% ASCs.

\section{Adding ASCs increased the synthesis of dermal proteins and} accelerated dermal maturation

Figure 3 shows the expression of dermal proteins such as decorin. Its labeling appeared throughout the dermis in the form of protein clusters, and more significantly in the upper dermis, underlying the dermoepidermal junction. This localized labelling may define a dermal region synthesized by fibroblasts in culture, which can be called "papillarylike dermis" (Figure 3A). This "papillary-like dermis" appeared thicker on D42 in reconstructed skin containing ASCs. As with the epidermis, the effect was greatest when $25 \%$ ASCs were added to $75 \%$ fibroblasts. Indeed, compared with the controls, the average increase in thickness was significant regardless of the percentage of ASCs added, since the thickness of the "papillary-like dermis" was equal to $109.9 \mu \mathrm{m}$ with $25 \%$ ASCs $(\mathrm{p}=0.05), 95.22 \mu \mathrm{m}$ with $50 \%(\mathrm{p}=0.05)$ and only $57.07 \mu \mathrm{m}$

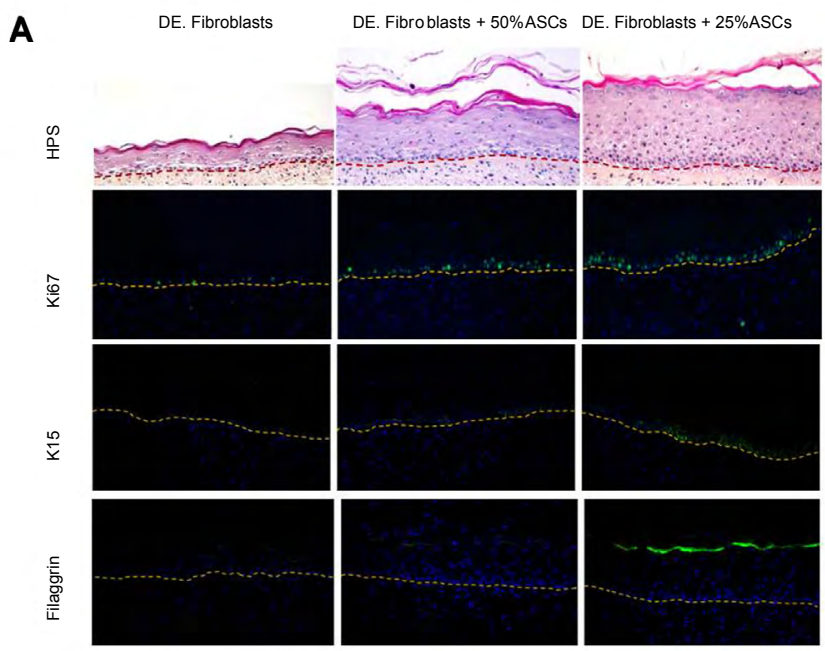

B

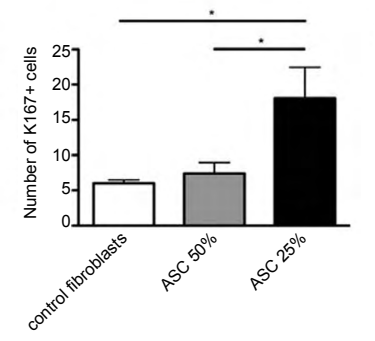

C

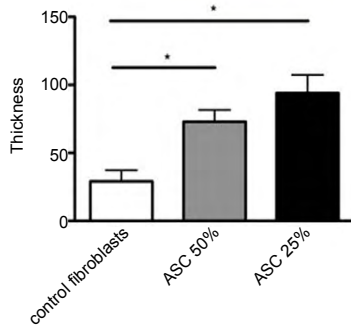

Figure 1: Influence of ASCs on the epidermal characteristics of skin equivalents when the dermal equivalent (DE) is prepared with or without ASCs on D42. A: Morphological analysis using HPS staining, Ki67, K15, and filaggrin expression. $\mathrm{K} 15$ is rarely expressed when the skin is reconstructed using fibroblasts alone, weakly with $50 \% / 50 \%$ density and strongly with a density of $75 \%$ fibroblasts and $25 \%$ ASCs. Filaggrin, was highly expressed when $25 \%$ ASCs were added to the fibroblasts during skin reconstruction and weakly expressed when $50 \%$ were added. On the other hand, in control epidermis with $100 \%$ fibroblasts (i.e. $0 \%$ ASCs), its expression was only just detectable. B: Comparison of cellular proliferation in SE with different amounts of ASCs (number of proliferating cells expressing Ki67 per field). The number of Ki67-positive cells, a proliferation marker, had significantly increased $(p=0.05)$ when fibroblasts and ASCs were seeded at a $75 \% / 25 \%$ density with a value of $18 \mathrm{Ki} 67$ positive-cells per field for this condition compared to a value of $6 \mathrm{Ki} 67$ positive-cells per filed for fibroblast alone, whereas with a $50 \% / 50 \%$ density of ASCs and fibroblasts alone, there was only a trend to increase at this culture time. C: Comparison of epidermal thickness $(\mu \mathrm{m})$ in SE with different amounts of ASCs. When DEs were seeded with cell suspension comprised $25 \%$ ASCs and $75 \%$ fibroblasts, the epidermal thickness was 3.2 times higher (with a value of $93,9 \mu \mathrm{m}$ ) than SEs prepared with $100 \%$ fibroblasts (with a value of $29,1 \mu \mathrm{m}$ ), whereas it was only 2.5 times higher with a DE prepared with $50 \%$ fibroblasts and $50 \%$ ASCs (with a value of $72,9 \mu \mathrm{m}$ ). Means calculated for 3 fields in 3 samples for each condition.

*Mann-Whitney test $p \leq 0.05$ 
Citation: Metral E, Santos MD, Thépot A, Rachidi W, Mojallal A, et al. (2014) Adipose-derived Stem Cells Promote Skin Homeostasis and Prevent its Senescence in an In vitro Skin Model. J Stem Cell Res Ther 4: 194. doi:10.4172/2157-7633.1000194

Page 5 of 10

A

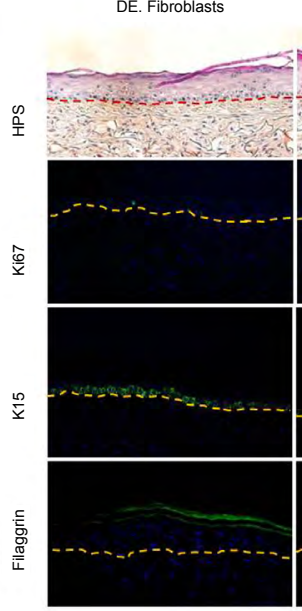

B

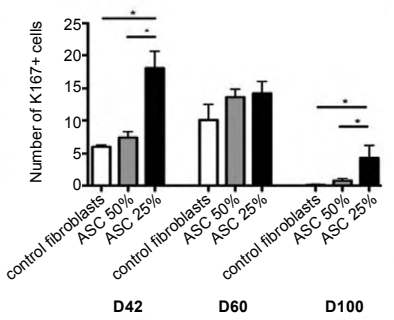

DE. Fibroblasts $+50 \%$ ASCs

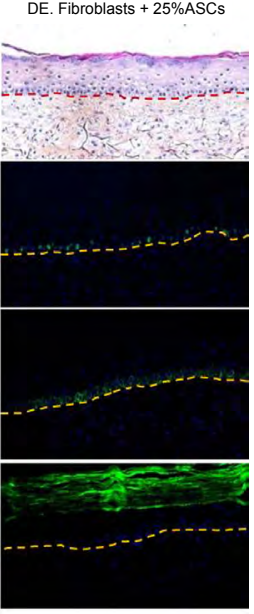

C

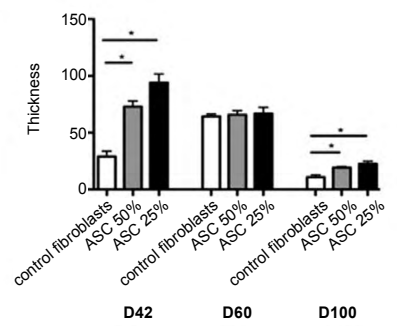

Figure 2: Effects of ASCs on the kinetics of epithelial regeneration and proliferation. A: Morphological analysis using HPS staining, Ki67, K15, and filaggrin expression on D60 (see figure1 for morphological analysis of D42 and figure 4 for that of D100) B: Comparison of cellular proliferation in SE with different amounts of ASCs (number of proliferating cells expressing Ki67 per field). C: Comparison of epidermal thickness $(\mu \mathrm{m})$ in SE with different amounts of ASCs. At D60, the epidermal thickness of the SE and the number of proliferating cells, labeled with Ki67 appeared similar (not statistically different) in SE with $25 \%, 50 \%$ and without ASCs. Means calculated for 3 fields in 3 different samples for each condition.

\section{${ }^{*}$ Mann-Whitney test $p \leq 0.05$}

without ASCs. On the other hand, the difference in decorin expression between the two ASC densities was not significant, although better results tended to be obtained with 25\% (Figure 3A and 3B).

Regarding fibrillin 1, a major elastic fibre protein, this was significantly greater after quantification by image analysis at D42 when $25 \%$ ASCs were added (Figure 3A). Indeed, the percentage of the area labelled with fibrillin relative to the total area of the dermis increased significantly when ASCs are added: $29.8 \%$ with $25 \%$ ASCs, $19.3 \%$ with $50 \%$ ASCs and $15.2 \%$ without ASCs ( $\mathrm{p}=0.05)$.

On the other hand, when the duration of culture was extended to 100 days, dermal homeostasis had been reached, and no difference was observed between the different conditions, concerning both the thickness of the "papillary-like dermis" and fibrillin expression (Figure 3C).

Taken together, these results suggested that ASCs accelerated maturation of the dermis, which matured later in the controls.

\section{Adding ASCs appears to slow down aging in reconstructed} skin

Extending the time of culture to 60 and 100 days mimicked skin

senescence in vitro: the epidermis became thinner and because of its greater fragility, peeled off easily when cut. On D100, Figure 4 shows that, with fibroblasts alone, the epithelium was fully differentiated into a stratum corneum devoid of nuclei and therefore presenting only 0.1 cells per field expressing proliferation markers such as Ki67. After this period of culture, only the addition of $25 \%$ ASCs maintained a living epidermis and the level of proliferating cells expressing Ki67 (Figure $4 \mathrm{~A}, 4 \mathrm{~B}$ and $4 \mathrm{C})$.

In the dermis, p16 commonly used as a senescent marker appeared weakly expressed in all short time culture SE (D42) whatever the cell culture conditions (controls, 50\% ASCs and 25\% ASCs) and dramatically increased along the prolonged culture SE (D100) notably on control SE prepared with fibroblasts alone (Figure 4A and 4D). In contrast, on D100, the presence of $25 \%$ ASCs significantly reduced its expression $(\mathrm{p}=0.05)$. Indeed, the percentage of area labelled with $\mathrm{p} 16$ in the dermis as compared to the total surface area of the dermis was $3.37 \%$ without ASCs and $2.33 \%$ with $25 \%$, resulting in percentage drop

A DE. Fibroblasts DE. Fibroblasts + 50\%ASCs DE. Fibroblasts $+25 \%$ ASCs

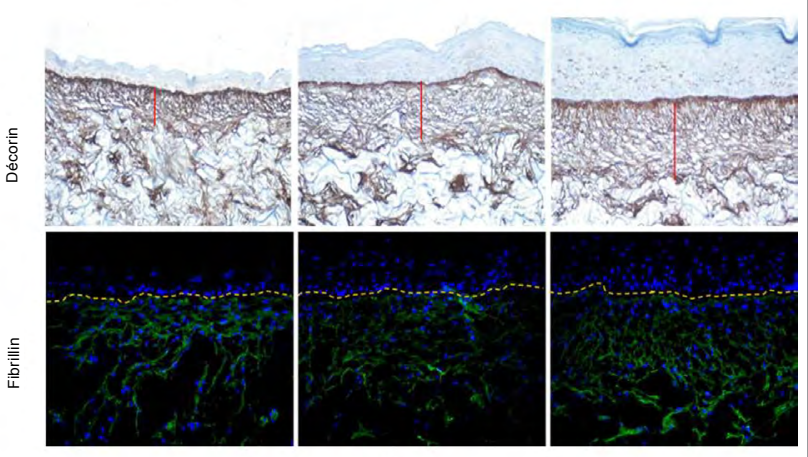

B

C
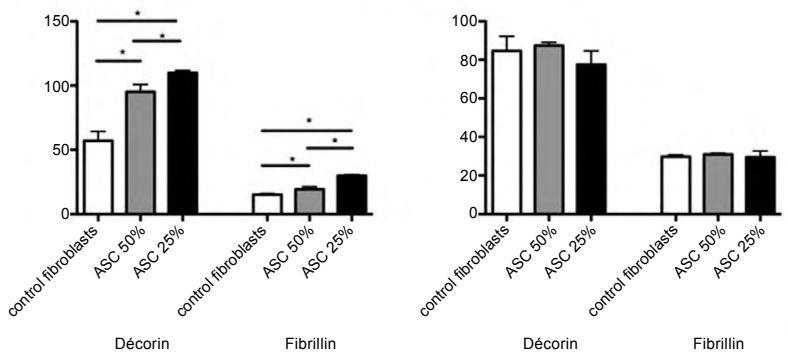

Figure 3: Effects of ASCs on decorin and fibrillin-1 synthesis in the DE of the SE. A: Morphological analysis using decorin and fibrillin expression on day 42. B: Thickness of "papillary-like" dermis $(\mu \mathrm{m})$ labeled by decorin and percentage of area labeled with fibrillin in relation to the total area of dermis on day 42. This "papillary-like dermis" appeared thicker on D42 in reconstructed skin containing ASCs with the greatest effect when $25 \%$ ASCs were added to $75 \%$ fibroblasts. Indeed, since the thickness of the "papillary-like dermis" was equal to $109.9 \mu \mathrm{M}$ with $25 \%$ ASCs ( $p=0.05$ ), $95.22 \mu \mathrm{M}$ with $50 \%$ ( $p=$ 0.05 ) and only $57.07 \mu \mathrm{M}$ without ASCs. The percentage of the area labeled with fibrillin relative to the total area of the dermis increased significantly when ASCs are added: $29.8 \%$ with $25 \%$ ASCs, $19.3 \%$ with $50 \%$ ASCs and $15.2 \%$ without ASCs $(p=0.05)$. C: Thickness of "papillary-like" dermis $(\mu \mathrm{m})$ labeled by decorin and percentage of area labeled with fibrillin in relation to the total area of dermis on day 100 . When the duration of culture was prolonged (to 100 days), dermal homeostasis had been reached and no difference was observed between the different conditions, concerning both the thickness of the "papillary-like dermis" and fibrillin expression. Means calculated for 3 fields in 3 different samples for each condition.

${ }^{*}$ Mann-Whitney test $p \leq 0.05$ 
Citation: Metral E, Santos MD, Thépot A, Rachidi W, Mojallal A, et al. (2014) Adipose-derived Stem Cells Promote Skin Homeostasis and Prevent its Senescence in an In vitro Skin Model. J Stem Cell Res Ther 4: 194. doi:10.4172/2157-7633.1000194

Page 6 of 10

to a level near to and statistically similar to that of young skin, which is around 2\% (D42). Moreover, whereas $\beta$-Galactosidase assay gave rare patches of low intensity blue dying for all D42 SEs, in D100 SE prepared with fibroblasts alone, patches in the dermis increased in number and intensity. However, in SE prepared with $25 \%$ of ASCs, the blue staining appeared close to that observed in short time SEs at D42, (Figure 4A).
Taken together, these results suggested that ASCs slow down senescence process of SE after extended-time cell culture.

\section{Discussion}

Our results clearly demonstrate the influence of ASCs on the development in vitro of the epidermis and dermis of reconstructed

A

d42

DE. Fibroblasts
I

I$$
\text { I }
$$
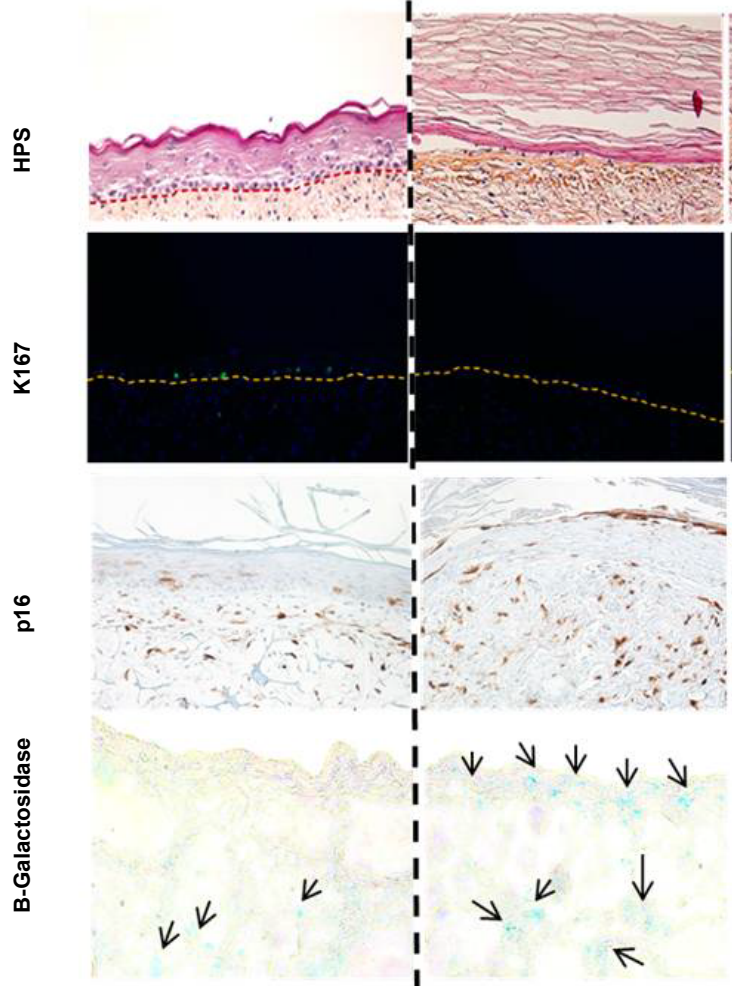

B

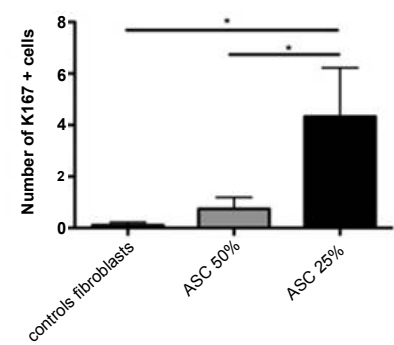

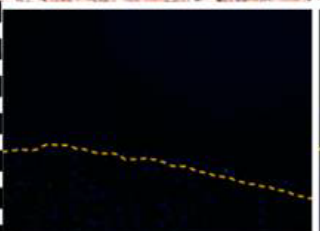

DE. Fibroblasts

$\kappa$ d100

DE. Fibroblasts + ASC $\mathbf{5 0} \%$

DE. Fibroblasts + ASC $25 \%$
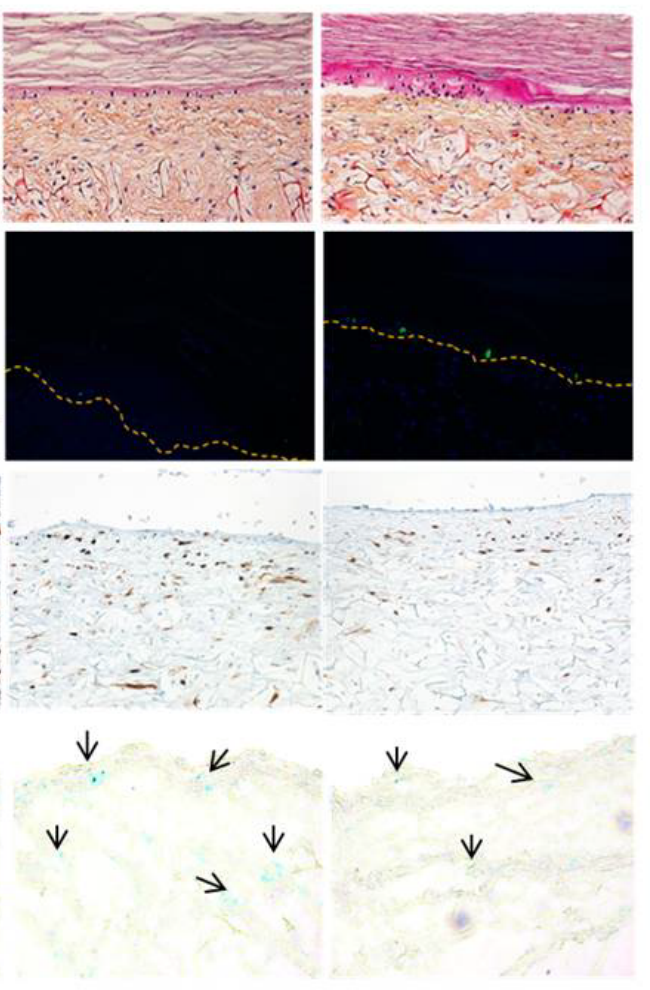

C

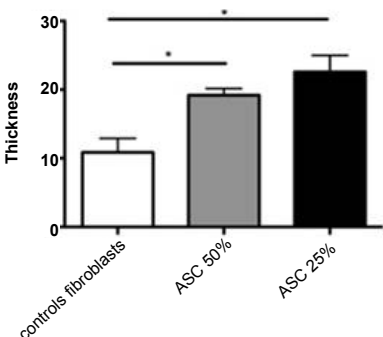

D

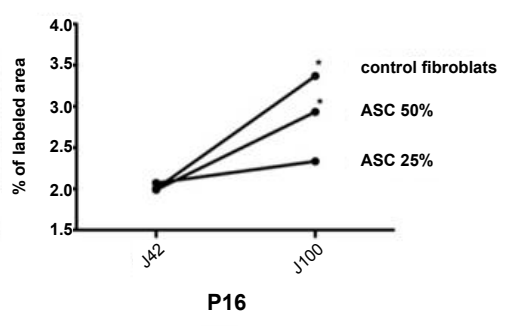

Figure 4: Influence of ASCs on senescence in vitro. A: Morphological analysis using HPS staining, Ki67 and p16 expression and B-Galactosidase assay. Comparison with the young control on D42 obtained with dermal equivalent prepared with fibroblasts which is similar to the young control on D42 obtained with each condition. $\beta$-Galactosidase assay gave rare patches of low intensity blue dying for all SEs from D42 and in SE of D100 prepared with fibroblasts alone, patches in the dermis increased in number and in intensity. However, in SE prepared with $25 \%$ of ASCs, the blue staining appears close to that observed in short time SEs at D42. B: number of proliferating cells expressing Ki67 on D100. C: Epidermal thickness on D100 $(\mu \mathrm{m})$. At D100, with fibroblasts alone, the epithelium was fully differentiated into a stratum corneum devoid of nuclei and therefore presenting only 0.1 cells per field expressing proliferation markers such as Ki67. After this period of culture, only the addition of $25 \%$ ASCs maintained a living epidermis and the level of proliferating cells expressing Ki67. D: Percentage area labeled with p16 in relation to total area of dermis on D42 (42) and D100 (100). On D100, the presence of 25\% ASCs significantly reduced its expression ( $p=0.05)$. Indeed, the percentage of area labeled with P16 in the dermis as compared to the total surface area of the dermis was $3.37 \%$ without ASCs and $2.33 \%$ with $25 \%$, resulting in percentage drop to a level near to and statistically similar to that of young skin, which is around $2 \%$ (D42). Means calculated for 3 fields in 3 samples for each condition.

"Mann-Whitney test $\mathrm{p} \leq 0.05$ 
skin. Indeed, the addition of ASCs to the fibroblast suspension, particularly at a density of $25 \%$, accelerates epithelialization of the dermal equivalent, resulting from a significant increase in cell proliferation and keratinocyte differentiation, thus maintaining tissue homeostasis. Indeed, we showed a significant keratinocyte proliferation as determined by increased Ki67-positive cells. On the other hand, the clusters of K15-expressing cells, originally known as a marker of stem cells of the hair follicle [60-63] and increasingly used as a marker of interfollicular stem cells $[63,64]$, increased in number, with more cells per cluster, when the SE was prepared with $25 \%$ ASCs too. This form of expression suggests that ASCs accelerate proliferation from these K15 expressing cells that proliferate and reconstitute "clusters" extending to the whole proliferating basal cell layer, such as in human skin cells where stem cells are grouped into clusters localized at the basal layer at the "tips" of the dermal papillae [65-67]. This resulted, on D42 corresponding to three weeks after seeding with keratinocytes, in a significantly thicker epidermis than with fibroblasts alone. Furthermore, the epidermis was stratified and differentiated into multilayers, with fully developed stratum basal, stratum spinosum, stratum granulosum and corneum. Our results are in concordance with those obtained from ASCs on the epidermal thickness in a collagen lattice $[68,69]$ when using $50 \%$ ASCs $/ 50 \%$ fibroblasts [70], whereas a $25 \%$ density was not tested and ASCs alone result in a loss of polarization of the epidermis [71]. Thus, in the same model (Bell), bone marrow stromal cells alone (BMSCs) also gives rise to a thinner and less well organized epidermis [72], consistent with ours when we completely replaced fibroblasts with ASCs in our SE sponge model (Figure 5). Finally, in unsupported selfassembling models of DE, an identical effect of both fibroblasts and ASCs alone on the development of the epidermis was observed [73] whereas others authors have shown that ASCs alone give a thicker epidermis than fibroblasts in a sponge model $[74,75]$.

Concerning the dermis, we are the first to show the effect of mixing ASCs and fibroblasts on dermal maturation on D42, with a significant increase, first, of the "papillary-like dermis" thickness as shown through decorin expression synthesized mainly by fibroblasts from the papillary dermis [76], and secondly of fibrillin 1 expression, the major fibrillar component in elastic tissue. Indeed, some authors have showed that MSCs from BM and fibroblasts showed the same capability to contract the gel and to secrete extracellular matrix (ECM) in a collagen lattice model [77] and that the replacement of fibroblasts by MSCs from BM or umbilical cord in Bell's model, gave disappointing results since DE is heterogeneous, with ECM aggregates (laminin, collagen and fibronectin) [71].

Moreover, if we consider the kinetics of skin reconstruction, adding 25\% ASCs accelerates epidermal maturation with a maximum thickness while also delaying senescence. The greatest number of Ki67-expressing proliferating cells are found on D42, explaining

DE. Fibroblasts

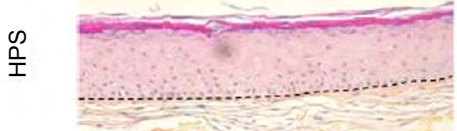

Figure 5: Comparison of SEs prepared with fibroblasts alone and SEs prepared with ASC alone. Morphological analysis using HPS staining. ASCs alone in dermis gave bad results with a very thin epidermis. the maximum epidermal thickness obtained. This peak value was never reached under other conditions. Differences fade over time as proliferating cell peaks are found later under other conditions, without reaching the same level. Furthermore, senescence of SE mimicked by an extended culture time and shown by a decrease in Ki67-expressing basal cells in the epidermis and with $\beta$-galactosidase staining in the dermis. Moreover, even if protein p16 plays roles in a variety of cell functions, it has been shown as a marker of senescence [78]. Recently, p16 in human skin has been reported to reflect biological age as younger biological age is associated with lower levels of p16 positive cells [79]. In our model, p16 expression dramatically increased along the prolonged culture SE. However, when ASCs are added at $25 \%$ levels, the appearance of dermal fibroblast senescence labelled with p16 is significantly reduced compared to other conditions.

Compared to other SE models in a collagen gel in which senescence is fast [80], our model kept SE alive for more than 100 days, so for a potentially longer use in pharmaco-toxicological applications or basic research. In Bell's model, cells trapped into the collagen lattice had their proliferation and synthesis inhibited. In addition, activated metalloproteinases cause rapid degradation of the model [81].

The good results obtained in our model after the addition of ASCs are similar to the increase in skin thickness obtained in vivo by injection of AT in humans [10], and cultured ASCs in mice [37,52,82], minipig [83] and pig [51], and these results on the dermis and epidermis show that ASCs had the greatest effect with a ratio of ASCs to fibroblasts of 1:3 and not 1:1, suggesting an inverse effect proportional to the amount of ASCs added. Indeed, even though the ASCs are of mesenchymal origin, like fibroblasts, the former retain their own specificity and are essential for a SE of quality under our culture conditions [84]. To support these results, two mechanisms of action could be suggested: paracrine effect and transdifferentiation. The most probable is the paracrine effect of ASCs. Indeed, ASCs secrete a large number of cytokines and/or growth factors such as bFGF, VEGF, KGF, TGF- $\beta$, PDGF and HGF $[44,83]$ acting on keratinocyte proliferation $[37,38,41,42,83]$ and migration [42] as well as that of fibroblasts $[37-39,41,43,44]$ and their synthesis [37-39,41,43,44]. Differentiation may also be suggested. Indeed, the improved development of the dermis can be the result of the differentiation of ASCs into papillary or younger fibroblasts, metabolically more active. Effectively, as multipotent stem cells, ASCs have the capacity to differentiate into fibroblasts [49]. Hence, in SE with $25 \%$ ASCs, the fibroblast-rich dermis provides a better quality DE, which in turn affects the quality of the epidermis, as previously shown $[84,85]$. Moreover, transdifferentiation of ASC into epithelial cells $[50,85-90]$ and migration toward the epidermis cannot be excluded.

Their full mechanism of action has yet to be clarified using our reconstructed skin model. Indeed, with this model, the use of GFPlabelled ASCs may allow to follow them in the dermis and/or the epidermis along the culture and observe if they migrate, proliferate and transdifferentiate or just die. In addition, this experiment may be completed by analyzing the morphological, cellular, biological and genomic changes in the dermis and the epidermis in order to elucidate the mode of action of ASCs on the improvement of skin quality observed in vivo after adipose tissue, SVF and ASC injection. Moreover, the mechanisms of action of ASCs may also be studied in others various conditions, such as wound healing by creating cutaneous lesions or photoaging by exposition to UVs. Finally, its longer life time compared to others models allows its use for long term tests.

To conclude, the addition of ASCS to fibroblasts in our SE model 
has led to improvements not only in the epidermis, but also the dermis, confirming the clinical results on skin quality observed during injection of adipose tissue according to Coleman suggesting also their anti-aging effect and their potential in wound healing.

\section{References}

1. Hayflick L (1985) The cell biology of aging. Clin Geriatr Med 1(1): 15-27. [PubMed]

2. Hayflick L (1985) Theories of biological aging. Exp Gerontol 20(3-4): 145-159. [PubMed]

3. Boisnic S (2005) Vieillissement cutané chronologique. EMC-Dermatologie Cosmétologie 2: 232-241

4. El-Aal NH, El-Wadood FA, Moftah NH, El-Hakeem MS, El-Shaal AY, et al. (2012) Morphometry and epidermal fas expression of unexposed aged versus young skin. Indian J Dermatol 57(3): 181-186.

5. Branchet MC, Boisnic S, Frances C, Robert AM (1990) Skin thickness changes in normal aging skin. Gerontology 36(1): 28-35.[PubMed]

6. Gunin AG, Kornilova NK, Petrov VV, Vasil'eva OV (2011) Age-related changes in the number and proliferation of fibroblasts in the human skin. Adv Geronto 24(1): 43-47.[PubMed]

7. Rittie L, Fisher GJ (2002) UV-light-induced signal cascades and skin aging Ageing Res Rev 1(4): 705-720.[PubMed]

8. Pons-Guiraud A (2004) Matériaux de comblement : techniques et effets indésirables. ECM Derm Cosm 1(1): 59-74.

9. Coleman SR (2001) Structural fat grafts: the ideal filler? Clin Plast Surg 28(1): 111-119.[PubMed]

10. Coleman SR (2006) Structural fat grafting: more than permanent filler. Plast Reconstr Surg 118(3 Suppl): 108S-20S.[PubMed]

11. Neuber G (1983) Fett transplantation. Verl Dtsch Ges Chir 22: 66.

12. Lexer E (1910) Freie fett transplantation. Dtsch Med 36: 640.[PubMed]

13. Coleman SR (2002) Hand rejuvenation with structural fat grafting. Plast Reconstr Surg 110(7): 1731-1744; discussion 45-47.

14. Serra-Renom JM, Munoz-Olmo JL, Serra-Mestre JM (2010) Fat grafting in postmastectomy breast reconstruction with expanders and prostheses in patients who have received radiotherapy: formation of new subcutaneous tissue. Plast Reconstr Surg 125(1): 12-18.

15. Tabit CJ, Slack GC, Fan K, Wan DC, Bradley JP (2012) Fat grafting versus adipose-derived stem cell therapy: distinguishing indications, techniques, and outcomes. Aesthetic Plast Surg 36(3): 704-713.

16. Gronthos S, Franklin DM, Leddy HA, Robey PG, Storms RW, et al. (2001) Surface protein characterization of human adipose tissue-derived stromal cells. J Cell Physiol 189(1): 54-63.[PubMed]

17. De Ugarte DA, Morizono K, Elbarbary A, Alfonso Z, Zuk PA, et al. (2003) Comparison of multi-lineage cells from human adipose tissue and bone marrow. Cells Tissues Organs 174(3): 101-119.[PubMed]

18. Zuk PA, Zhu M, Ashjian P, De Ugarte DA, Huang JI, et al. (2002) Human adipose tissue is a source of multipotent stem cells. Mol Biol Cell 13(12): 42794295.[PubMed]

19. Zuk PA, Zhu M, Mizuno H, Huang J, Futrell JW, et al. (2001) Multilineage cells from human adipose tissue: implications for cell-based therapies. Tissue Eng 7(2): 211-228.[PubMed]

20. Yoshimura K, Sato K, Aoi N, Kurita M, Hirohi T, et al. (2008) Cell-assisted lipotransfer for cosmetic breast augmentation: supportive use of adiposederived stem/stromal cells. Aesthetic Plast Surg 32(1): 48-55.[PubMed]

21. Yoshimura K, Sato K, Aoi N, Kurita M, Inoue K, et al. (2008) Cell-assisted lipotransfer for facial lipoatrophy: efficacy of clinical use of adipose-derived stem cells. Dermatol Surg 34(9):1178-1185.[PubMed]

22. He X, Zhong X, Ni Y, Liu M, Liu S, et al. (2013) Effect of ASCs on the graft survival rates of fat particles in rabbits. J Plast Surg Hand Surg 47(1): 3-7. [PubMed]

23. Matsumoto D, Sato K, Gonda K, Takaki Y, Shigeura T, et al. (2006) Cellassisted lipotransfer: supportive use of human adipose-derived cells for sof tissue augmentation with lipoinjection. Tissue Eng 12(12): 3375-3382.[PubMed]
24. Moseley TA, Zhu M, Hedrick MH (2006) Adipose-derived stem and progenito cells as fillers in plastic and reconstructive surgery. Plast Reconstr Surg 118(3 Suppl):121S-128S.[PubMed]

25. Sterodimas A, de Faria J, Nicaretta B, Papadopoulos O, Papalambros E, et al (2010) Cell-assisted lipotransfer. Aesthet Surg J 30(1): 78-81.[PubMed]

26. Guilak F, Awad HA, Fermor B, Leddy HA, Gimble JM (2004) Adipose-derived adult stem cells for cartilage tissue engineering. Biorheology 41(3-4): 389-399. [PubMed]

27. Lei L, Liao W, Sheng P, Fu M, He A, et al. (2007) Biological character of human adipose-derived adult stem cells and influence of donor age on cell replication in culture. Sci China C Life Sci 50(3): 320-328.[PubMed]

28. Strem BM, Hicok KC, Zhu M, Wulur I, Alfonso Z, et al. (2005) Multipotential differentiation of adipose tissue-derived stem cells. Keio J Med 54(3):132-141. [PubMed]

29. Yoshimura K, Shigeura T, Matsumoto D, Sato T, Takaki Y, et al. (2006) Characterization of freshly isolated and cultured cells derived from the fatty and fluid portions of liposuction aspirates. J Cell Physiol 208(1): 64-76.[PubMed]

30. Lompros V (2010) IFATS Meetings, Dallas.

31. Beeson W, Woods E, Agha R (2011) Tissue engineering, regenerative medicine, and rejuvenation in 2010: the role of adipose-derived stem cells. Facial Plast Surg 27(4): 378-387.[PubMed]

32. Moioli EK, Chen M, Yang R, Shah B, Wu J, et al. (2010) Hybrid adipogenic implants from adipose stem cells for soft tissue reconstruction in vivo. Tissue Eng Part A 16(11): 3299-3307.[PubMed]

33. Altman AM, Yan Y, Matthias N, Bai X, Rios C et al. (2009) IFATS collection: Human adipose-derived stem cells seeded on a silk fibroin-chitosan scaffold enhance wound repair in a murine soft tissue injury model. Stem Cells 27(1) 250-258.[PubMed]

34. Garcia-Olmo D, Herreros D, Pascual M, Pascual I, De-La-Quintana P, et al (2009) Treatment of enterocutaneous fistula in Crohn's Disease with adiposederived stem cells: a comparison of protocols with and without cell expansion Int J Colorectal Dis 24(1): 27-30.[PubMed]

35. Nie C, Yang D, Xu J, Si Z, Jin X, et al. (2011) Locally administered adiposederived stem cells accelerate wound healing through differentiation and vasculogenesis. Cell Transplant 20(2): 205-216.[PubMed]

36. Kim WS, Park BS, Kim HK, Park JS, Kim KJ, et al. (2008) Evidence supporting antioxidant action of adipose-derived stem cells: protection of human derma fibroblasts from oxidative stress. J Dermatol Sci 49(2):133-142.[PubMed]

37. Kim WS, Park BS, Sung JH (2009) The wound-healing and antioxidant effects of adipose-derived stem cells. Expert Opin Biol Ther 9(7): 879-887.[PubMed]

38. Kim WS, Park BS, Sung JH (2009) Protective role of adipose-derived stem cells and their soluble factors in photoaging. Arch Dermatol Res 301(5): 329336.[PubMed]

39. Kim WS, Park BS, Sung JH, Yang JM, Park SB, et al. (2007) Wound healing effect of adipose-derived stem cells: a critical role of secretory factors on human dermal fibroblasts. J Dermatol Sci 48(1):15-24.[PubMed]

40. Lee EY, Xia Y, Kim WS, Kim MH, Kim TH, et al. (2009) Hypoxia-enhanced wound-healing function of adipose-derived stem cells: increase in stem cell proliferation and up-regulation of VEGF and bFGF. Wound Repair Regen 17(4): 540-547. [PubMed]

41. Lee SH, Jin SY, Song JS, Seo KK, Cho KH (2012) Paracrine effects of adiposederived stem cells on keratinocytes and dermal fibroblasts. Ann Dermato 24(2):136-143. [PubMed]

42. Moon KM, Park YH, Lee JS, Chae YB, Kim MM, et al. (2012) The effect of secretory factors of adipose-derived stem cells on human keratinocytes. Int $J$ Mol Sci 13(1):1239-1257. [PubMed]

43. Smith AN, Willis E, Chan VT, Muffley LA, Isik FF, et al. (2010) Mesenchyma stem cells induce dermal fibroblast responses to injury. Exp Cell Res 316(1) 48-54. [PubMed]

44. Song SY, Jung JE, Jeon YR, Tark KC, Lew DH (2011) Determination of adipose-derived stem cell application on photo-aged fibroblasts, based on paracrine function. Cytotherapy 13(3): 378-384. [PubMed] 
45. Ghannam S, Bouffi C, Djouad F, Jorgensen C, Noel D (2010) Immunosuppression by mesenchymal stem cells: mechanisms and clinical applications. Stem Cell Res Ther 1(1): 2. [PubMed]

46. Nauta AJ, Fibbe WE (2007) Immunomodulatory properties of mesenchymal stromal cells. Blood 110(10): 3499-3506. [PubMed]

47. Paunescu V, Deak E, Herman D, Siska IR, Tanasie G, et al. (2007) In vitro differentiation of human mesenchymal stem cells to epithelial lineage. $J$ Cell Mol Med 11(3): 502-508. [PubMed]

48. Rehman J, Traktuev D, Li J, Merfeld-Clauss S, Temm-Grove CJ, et al. (2004) Secretion of angiogenic and antiapoptotic factors by human adipose stromal cells. Circulation 109(10):1292-1298. [PubMed]

49. Tobita M, Orbay H, Mizuno H (2011) Adipose-derived stem cells: current findings and future perspectives. Discov Med 11(57):160-170. [PubMed]

50. Yan Y, Liu Y, Liu D, He L, Guan L, et al. (2013) Differentiation of adiposederived adult stem cells into epithelial-like stem cells. Ann Anat 195(3): 212 218. [PubMed]

51. Lequeux C, Oni G, Wong C, Damour O, Rohrich R, et al. (2012) Subcutaneous fat tissue engineering using autologous adipose-derived stem cells seeded onto a collagen scaffold. Plast Reconstr Surg 130(6):1208-1217.[PubMed]

52. Mojallal A, Lequeux C, Shipkov C, Breton P, Foyatier JL, et al (2009) Improvement of skin quality after fat grafting: clinical observation and an animal study. Plast Reconstr Surg 124(3): 765-774. [PubMed]

53. Mojallal A, Auxenfans C, Lequeux C, Braye F, Damour O (2008) Influence of negative pressure when harvesting adipose tissue on cell yield of the stromalvascular fraction. Biomed Mater Eng 18(4-5):193-197. [PubMed]

54. Bjorntorp P, Karlsson M, Pertoft H, Pettersson P, Sjostrom L, et al (1978) Isolation and characterization of cells from rat adipose tissue developing into adipocytes. J Lipid Res 19(3): 316-324. [PubMed]

55. Rheinwald JG, Green H (1975) Serial cultivation of strains of human epidermal keratinocytes: the formation of keratinizing colonies from single cells. Cell 6(3): 331-343. [PubMed]

56. Lequeux C, Auxenfans C, Mojallal A, Sergent M, Damour O (2009) Optimization of a culture medium for the differentiation of preadipocytes into adipocytes in a monolayer. Biomed Mater Eng 19(4-5): 283-291. [PubMed]

57. Auxenfans C, Lequeux C, Perrusel E, Mojallal A, Kinikoglu B, et al. (2012) Adipose-derived stem cells (ASCs) as a source of endothelial cells in the reconstruction of endothelialized skin equivalents. J Tissue Eng Regen Med 6(7): 512-518. [PubMed]

58. Shahabeddin L, Berthod F, Damour O, Collombel C (1990) Characterization of skin reconstructed on a chitosan-cross-linked collagen-glycosaminoglycan matrix. Skin Pharmacol 3(2):107-114. [PubMed]

59. Black AF, Bouez C, Perrier E, Schlotmann K, Chapuis F, et al. (2005) Optimization and characterization of an engineered human skin equivalent. Tissue Eng 11(5-6): 723-733. [PubMed]

60. Bose A, Teh MT, Hutchison IL, Wan H, Leigh IM, et al. (2012) Two mechanisms regulate keratin K15 expression in keratinocytes: role of PKC/AP-1 and FOXM1 mediated signalling. PLoS One 7(6): e38599. [PubMed]

61. Liu Y, Lyle S, Yang Z, Cotsarelis G (2003) Keratin 15 promoter targets putative epithelial stem cells in the hair follicle bulge. J Invest Dermatol 121(5): 963-968. [PubMed]

62. Sieber-Blum M (2011) Epidermal stem cell dynamics. Stem Cell Res Ther 2(3): 29. [PubMed]

63. Roh C, Roche M, Guo Z, Photopoulos C, Tao Q, et al. (2008) Multi-potentiality of a new immortalized epithelial stem cell line derived from human hair follicles. In vitro Cell Dev Biol Anim 44(7): 236-244. [PubMed]

64. Omoto M, Miyashita H, Shimmura S, Higa K, Kawakita T, et al. (2009) The use of human mesenchymal stem cell-derived feeder cells for the cultivation of transplantable epithelial sheets. Invest Ophthalmol Vis Sci 50(5): 2109-2115. [PubMed]

65. Jensen KB, Watt FM (2006) Single-cell expression profiling of human epiderma stem and transit-amplifying cells: Lrig1 is a regulator of stem cell quiescence. Proc Natl Acad Sci U S A 103(32):11958-11963. [PubMed]

66. Jones PH, Harper S, Watt FM (1995) Stem cell patterning and fate in human epidermis. Cell 80(1): 83-93. [PubMed]
67. Legg J, Jensen UB, Broad S, Leigh I, Watt FM (2003) Role of melanoma chondroitin sulphate proteoglycan in patterning stem cells in human interfollicular epidermis. Development 130(24): 6049-6063. [PubMed]

68. Bell E, Ehrlich HP, Buttle DJ, Nakatsuji T (1981) Living tissue formed in vitro and accepted as skin-equivalent tissue of full thickness. Science 211(4486):1052 1054. [PubMed]

69. Bell E, Ehrlich HP, Sher S, Merrill C, Sarber R, et al. (1981) Development and use of a living skin equivalent. Plast Reconstr Surg 67(3): 386-392. [PubMed]

70. Lu W, Yu J, Zhang Y, Ji K, Zhou Y, et al. (2012) Mixture of fibroblasts and adipose tissue-derived stem cells can improve epidermal morphogenesis of tissue-engineered skin. Cells Tissues Organs 195(3):197-206. [PubMed]

71. Schneider RK, Anraths J, Kramann R, Bornemann J, Bovi M, et al. (2010) The role of biomaterials in the direction of mesenchymal stem cell properties and extracellular matrix remodelling in dermal tissue engineering. Biomaterials 31(31): 7948-7959. [PubMed]

72. Aoki S, Toda S, Ando T, Sugihara H (2004) Bone marrow stromal cells preadipocytes, and dermal fibroblasts promote epidermal regeneration in their distinctive fashions. Mol Biol Cell 15(10): 4647-4657.[PubMed]

73. Trottier V, Marceau-Fortier G, Germain L, Vincent C, Fradette J (2008) IFATS collection: Using human adipose-derived stem/stromal cells for the production of new skin substitutes. Stem Cells 26(10): 2713-2723. [PubMed]

74. Alexaki VI, Simantiraki D, Panayiotopoulou M, Rasouli O, Venihaki M et al. (2012) Adipose tissue-derived mesenchymal cells support skin reepithelialization through secretion of KGF-1 and PDGF-BB: comparison with dermal fibroblasts. Cell Transplant 21(11): 2441-2454. [PubMed]

75. Van den Broek LJ, Niessen FB, Scheper RJ, Gibbs S (2012) Development, validation and testing of a human tissue engineered hypertrophic scar model. ALTEX 29(4): 389-402. [PubMed]

76. Schonherr E, Beavan LA, Hausser H, Kresse H, Culp LA (1993) Differences in decorin expression by papillary and reticular fibroblasts in vivo and in vitro. Biochem J 290 ( Pt 3): 893-899. [PubMed]

77. Fioretti F, Lebreton-DeCoster C, Gueniche F, Yousfi M, Humbert P, et al (2008) Human bone marrow-derived cells: an attractive source to populate dermal substitutes. Wound Repair Regen 16(1): 87-94. [PubMed]

78. Zhang W1, Hu D, Ji W, Yang L, Yang J, et al. (2014) Histone modifications contribute to cellular replicative and hydrogen peroxide-induced premature senescence in human embryonic lung fibroblasts. Free Radic Res (10). [PubMed]

79. Waaijer ME, Parish WE, Strongitharm BH, van Heemst $D$, Slagboom PE, et al (2012) The number of $\mathrm{p} 16 \mathrm{INK} 4 \mathrm{a}$ positive cells in human skin reflects biological age. Aging Cell 11(4): 722-725. [PubMed]

80. El Ghalbzouri A, Commandeur S, Rietveld MH, Mulder AA, Willemze R (2009) Replacement of animal-derived collagen matrix by human fibroblast-derived dermal matrix for human skin equivalent products. Biomaterials 30(1): 71-78. [PubMed]

81. Berthod F, Hayek D, Damour O, Collombel C (1993) Collagen synthesis by fibroblasts cultured within a collagen sponge. Biomaterials 14(10): 749-754 [PubMed]

82. Mojallal A, Lequeux C, Auxenfans C, Braye F, Damour O (2008) Does adipose tissue cultured with collagen matrix and preadipocytes give comparable results to the standard technique in plastic surgery? Biomed Mater Eng 18(4-5):187192. [PubMed]

83. Park BS, Jang KA, Sung JH, Park JS, Kwon YH, et al. (2008) Adipose-derived stem cells and their secretory factors as a promising therapy for skin aging. Dermatol Surg 34(10):1323-1326. [PubMed]

84. Goulet F, Poitras A, Rouabhia M, Cusson D, Germain L, et al. (1996) Stimulation of human keratinocyte proliferation through growth factor exchanges with dermal fibroblasts in vitro. Burns 22(2):107-112. [PubMed]

85. Lacroix S, Bouez C, Vidal S, Cenizo V, Reymermier C, et al. (2007) Supplementation with a complex of active nutrients improved dermal and epidermal characteristics in skin equivalents generated from fibroblasts from young or aged donors. Biogerontology 8(2): 97-109. [PubMed]

86. Brzoska M Geiger H, Gauer S, Baer P (2005) Epithelial differentiation of human adipose tissue-derived adult stem cells. Biochem Biophys Res Commun 330(1): 142-150. [PubMed] 
Citation: Metral E, Santos MD, Thépot A, Rachidi W, Mojallal A, et al. (2014) Adipose-derived Stem Cells Promote Skin Homeostasis and Prevent its Senescence in an In vitro Skin Model. J Stem Cell Res Ther 4: 194. doi:10.4172/2157-7633.1000194

Page 10 of 10

87. Chavez-Munoz C, Nguyen KT, Xu W, Hong SJ, Mustoe TA, et al. (2013) Transdifferentiation of adipose-derived stem cells into keratinocyte-like cells: engineering a stratified epidermis. PLoS One 8(12): e80587. [PubMed]

88. Li H, XuY, Fu Q, Li C (2012) Effects of multiple agents on epithelial differentiation of rabbit adipose-derived stem cells in 3D culture. Tissue Eng Part A 18(17-18): 1760-1770. [PubMed]
89. Ravichandran R, Venugopal J. R, Sundarrajan S, Mukherjee S, Forsythe J, et al. (2013) Click chemistry approach for fabricating PVA/gelatin nanofibers for the differentiation of ADSCs to keratinocytes. J Mater Sci Mater Med 24(12): 2863-2871. [PubMed]

90. Ventayol M, Vinas JL, Sola A, Jung M, Brune B (2014) miRNA let-7e targeting MMP9 is involved in adipose-derived stem cell differentiation toward epithelia. Cell Death Dis 5: e1048. [PubMed] 